\title{
Libraries in the American Way of Life
}

The possible role of libraries in advancing American aims and ideals is shown by Dr. McDiarmid to be anything but a passive one.

\begin{abstract}
$A^{n}$
MERICAN LIBRARIES face today a great opportunity, one peculiarly American, and one which promises to further the American way of life.

Many years ago Thomas Jefferson said:

Societies exist in three forms sufficiently distinguishable. I. Without government, as among our Indians. 2. Under governments wherein the will of everyone has a just influence, as is the case in England in a slight degree and in our own states in a great one. 3. Under, governments of force, as is the case in all other monarchies and in most of the other republics.
\end{abstract}

Although Jefferson was speaking for other times, his words are particularly apt for the present. For we are now engaged in a war which will determine whether we can have "a government wherein the will of everyone has a just influence." Our enemies have amply demonstrated that they believe in force alone and that they have no place in their scheme of things for intellect, reason, or will. We are fighting for the right to choose-to choose our own form of government, to choose our own leaders, to choose our own social institutions.

The right to choose, as does every human right, carries with it a corresponding responsibility, that of making choices through

1 Talk given before the annual meeting of the Range Library Trustees Association of Minnesota. processes of reason rather than of emotion. But, unhappily, we in America have too often exercised the right without fulfilling the responsibility. We often select our course, not because of the weight of the argument behind it, but because of the volume of words used in support of it or the personality of the man who is urging it.

There is no better illustration of this than the furor raised over the report several years ago of the President's Committee on Administrative Management. That committee proposed several reforms in the organization of the executive branch of the national government-reforms, incidentally, which had been urged previously by a Republican administration. Whatever the merits of the proposals, many of them were defeated, not because they were carefully examined and found wanting, but because their opponents applied to the bill the term "dictator bill." Hatred for anything resembling dictatorship clouded reason, and many of the proposals were never considered on their merits alone.

If our American way of life is to survive, our choices must be made on the basis of reason rather than emotion, and American libraries can make a significant contribution here. On the shelves of libraries are materials which, if studied carefully, will give us the best thought and judgment of all time on almost any problem. The library's job is to make these materials so accessible and so usable that the American people will look to the library for factual information 
on which decisions can be based. Libraries cannot decide for the voters but can furnish data which will aid in arriving at intelligent conclusions. Hence, the first responsibility of libraries is to help people decide political, social, and economic questions on the basis of reason rather than emotion and to be ever ready to supply the facts necessary for this.

A second responsibility is what may be called keeping alive the learning process. Libraries must do all in their power to stimulate intellectual curiosity and to encourage people to learn, not only during the school years, but also after formal education has ceased.

In his Among My Books, James Russell Lowell said:

It was in making education not only common to all, but in some sense compulsory on all, that the destiny of the free republics of America was practically settled.

Our youth are legally compelled to go to school up through certain years. But there is a greater compulsion than that requiring a certain number of years in the classroom - the compulsion that falls on every person in society of not only being educated along his own special lines but along other lines that have social implications. Because of the kind of society we have, doctors must not only know medicine but they must know something of law and economics and politics. There is almost no profession or trade in which Americans can cloister themselves and have no need of knowledge outside of their own fields.

Again, in our formal school system, students often come to think of learning as something to be done in connection with specific courses but not for life itself. Consequently when a student finishes his formal education, he ceases to think of books and magazines as sources of learning because there are no direct course assignments for which he is required to use them. Educa- tion needs to train students better in the seeking of information and in stimulating them to want to keep the learning process alive.

Libraries have an important responsibility in this respect. They have contact with the student both during his school years and after he has graduated. True, one may use one library for one purpose and another for the other, but, fortunately, libraries are very similar whether they are in high school, college, or city buildings. They have the same opportunity to build the will to learn and to nurture this spirit, even after the necessity for securing passing marks has ceased.

\section{World Understanding}

A third thing libraries can do is to encourage world-wide understanding. There are discussions every day of the kind of world order needed to preserve peace among nations after this war is ended. The proposals offered vary from out-and-out military alliances to loose voluntary cooperation. It seems agreed, however, that there must be better understanding among all nations; and libraries can, if they will, render a great service by allying themselves on the side of promoting international consciousness among all nations and to all of their clientele. This cannot be done by promoting any one scheme of international organization, but by studying carefully the history, geography, and sociology of other nations and by keeping continually before the patrons of the library such materials as remind them that this is one world.

As a fourth possibility, libraries are in a peculiarly favorable position to foster American art and letters. One hundred years ago Sydney Smith wrote the lines for which he is perhaps most famous:

In the four quarters of the globe, who reads an American book, or goes to an American 
play, or looks at an American picture or statue?

After that time it became somewhat fashionable to deprecate anything American whether it was in the library, museum, or music hall. And yet when one reflects that the pilgrims first set foot on American soil only three hundred years ago, one has reason to be proud of the contribution America has made to culture and learning. True, there has not yet been produced a Shakespeare, a Rembrandt, or a Beethoven, but there have been produced men of the stature of Edgar Allan Poe, Winslow Homer, and Edward MacDowell. And, what is more significant, American art and letters have reflected a spirit truly American, a spirit of pioneering, of enthusiasm and vigor. And even if America's contribution to date is small, it has resources which, if exploited, may produce a culture equal to that of any nation anywhere.

What are some of these resources? First, as the melting pot of nations, America has the best from all countries with which to enrich its own contribution. The contribution of the freedom-loving strain of the Scandinavian peoples has done much to keep Minnesota forward-looking in politics, education, and literature. Second, America has rich material resources. And even though it has been slow in properly providing for the welfare of cultural leaders, it can and presumably will do so in a way that no nation can surpass. Third, there already are rich traditions from which to draw-those of the struggle for independence, of westward expansion, of the development of such treasure as lies in the Minnesota Iron Range. Finally, there is the spirit of energy and enthusiasm. The soldiers on many college campuses typify this spirit, singing lustily as they march to and from classes.

Time and proper support are all that are needed to develop cultural interests in this country to a high degree, and libraries can do their part to hasten the day when American art and letters will be unsurpassed among nations, by encouraging the production of cultural works.

\section{Our Cultural Heritage}

A fifth, and perhaps the most obvious, responsibility of libraries in furthering the American way of life is that of preserving the nation's cultural heritage. One aspect of this opportunity arises out of the fact that American culture has its origin in many parts of the world. In a sense, English, French, Scandinavian, and German history constitute the background of American history, for almost every European conflict has produced results which were reflected in America and the American colonies. To understand, too, the events which led to the discovery and exploration of the Western Hemisphere, we must know a great deal about the countries from which the voyagers started. One of the most important sources of early American history, for example, is the so-called series of Jesuit Relations, the reports which Jesuit missionaries to the New World sent back to headquarters.

What is being done to collect and preserve such materials? The large research libraries particularly have had this as one of their major objectives. Of great importance also has been the work of private collectors who, because of their love of books and learning, have bought and conserved the foundation material for American research. As long as America produces men with a love for culture and learning and the wealth with which to implement it, American libraries will be among the greatest in the world.

American scholarship has been pretty well served by the collection of early American source material. True, there are some 
things of which no copy has been saved, but such instances are rare. Early American books and manuscripts have had great appeal to collectors and thus have found their way eventually into libraries. It is true that on this score various sections of the country differ widely. For some reasons, certain areas have been much more concerned with their early history than others. Minnesota is one of the more fortunate of these-the Minnesota Historical Society with its fine library is the oldest surviving public institution in the state. A special emphasis now might well be on regional aspects of culture and learning. This, I believe, has particular application in the Minnesota Iron Range, for here there is a rich and romantic history, and it should be preserved for the future in the minutest detail. This should mean more than having an occasional book or two on the area; the official records, personal diaries, anecdotes, anything which helps to save for posterity things which now are common knowledge, should be preserved.

\section{Applies to Public Libraries}

What has been said is meant to apply just as much to small public libraries as to large research ones. The small public library does not have the resources to collect rare Americana, one scarce item of which may cost as much as the library spends on all books in one year. But it can easily do two very important things. It can stimulate among people who can afford it the urge to collect the great sources of American culture and thus help to see that such materials find their way into libraries, where they will be most useful to the scholar and student. Also, it can and should collect and preserve the source material of its own area.

\section{Supplementary Materials}

American history can no longer be studied solely from documents originating in Washington or books published in New York. To understand the past of Minnesota, one must have complete records, for instance, for Grand Rapids, Coleraine, Hibbing, and Virginia. And one must have the same for government units, such as Itasca County, St. Louis County, Hennepin County, and the cities located in them. Thus it becomes a matter of both local pride and responsibility to collect and preserve the source materials of one's region.

Such a policy even for small public libraries would have two important results. The first is obviously that thus would be preserved valuable material which soon might be irreparably lost. Second, such a policy would result in stimulation of local pride and interest, both of which would be directed toward the future as well as the past. Most communities have a history of which they can well be proud, and when their citizens grow to be concerned about it they will undoubtedly become better citizens. One need not be frightened by the cost. Many valuable records may be had for the asking, so that the only expense is that of storing them properly. Public libraries, even the smallest ones, may well see that the historical records of their communities are preserved and that the interest of their citizens is directed toward an understanding of their region's cultural antecedents. 